\title{
The establishment of the residential care facilities in the Transcarpathian region of the early XX century
}

\author{
M. T. Cherepania \\ Mukachevo State University, Mukachevo, Ukraine
}

Paper received 15.02.18; Accepted for publication 25.0218.

\section{http://doi.org/10.31174/SEND-PP2018-162VI66-03}

\begin{abstract}
Анотація. Стаття присвячена вивченню передумов та основних тенденцій у становленні закладів інтернатного типу в Закарпатті початку XX століття, яке входило до складу Австро-Угорщини. Зокрема, аналізуються угорські закони, які забезпечували соціальний захист дітей-сиріт та дітей, що потребували перебування в спеціалізованих закладах з інших причин, а також регламентували діяльність закладів інтернатного типу. В публікації подається історична довідка щодо діяльності закладів інтернатного типу Закарпаття з 1901 року по 1919 рік.
\end{abstract}

Ключові слова: дитячі притулки, заклади інтернатного типу, закони, Закарпаття, Австро-Угорщина.

\begin{abstract}
This article is devoted to the study of prerequisites and the main trends in the establishment of the residential care facilities in the Transcarpathian region of the early XX century, which was a part of Austro-Hungarian. In particular Hungarian laws are analyzed which had been providing the social protection for orphans and children who needed to stay in specialized institutions for other reasons. These laws also regulated the activities of the residential care facilities. The publication is accompanied by the historical reference concerning activity of residential care facilities of Transcarpathia since 1901 till 1919 year.
\end{abstract}

Keywords: children's shelters, the residential care facilities, laws, Transcarpathia, Austria-Hungary.

Introduction. Reforming of the national education system in Ukraine is a component of the social and economic life of the country. The stability of the state is determined by its attitude to the problems of children, to their interests and needs. After all children are the guarantor of selfpreservation and development of the nation. By investing resources in childhood the state strengthens future productive forces, provides stability and prepares future active citizens who are able to take over the management of public and social affairs, inherit spiritual priorities. The UN Convention "On the Rights of the Child" recognizing the priority of the interests of the child in society, emphasizes the inadmissibility of child discrimination by any signs and the right of every child to family upbringing and parental care, and at the same time this Convention denotes that the state should ensure appropriate care for the child if parents do not do this. This thesis is also enshrined in the Constitution of Ukraine according to which the state assumes the responsibility for the child's fate, her/his development and future takes over the state. Ukraine has a state system of social and educational institutions the purpose of which is to provide optimal conditions for the life of orphans and children deprived of parental care depending on the age and the child's condition. The optimization of functioning of boarding schools of education at the present stage is possible only on the basis of a thorough study of historical experience, the synthesis of such an experience with new scientific research, with the achievements of pedagogical theory and practice. It is quite obvious that modern scientific researches of the activity of educational institutions of the residential care facilities in the historical and pedagogical aspect are particularly relevant. Study of normative legal documents in the field of education and generalization of the experience of scientific achievements on the development of residential care facilities contributes to the understanding of the role of the boarding schools in the further improvement of the system of social upbringing of children.

Brief review of publications on the topic. In the historical and pedagogical dimension of the issues of formation, development and activity of the residential care facilities had studied V. Vynohradov-Bondarenko (the upbringing of homeless children in Ukraine in the twenties years of the XX century), L. Hrebinj (organizational and pedagogical principles of activity of the orphanage in the system of education of Ukraine in the twenties-mid-thirties of the XX century), V. Zolotoverkh (the establishment and development of preschool institutions for children with psychophysical defect in the system of special education of Ukraine of the end of XIX - early XX century), O. Parashevina (the role of the system of public education in overcoming of the child homelessness in the twenties and in the first half of the thirties years of the XX century in Ukraine), I. Pluhator (the theory and practice of child and youth care in Ukraine (1945-1990)), V. Pokasj (the establishment and development of the residential care facilities in Ukraine in 1917-2000 years), L. Ryabkyna (the social and educational activities of the boarding schools of the first half of the XX century), T. Yanchenko (the problems of social and pedagogical support of children who need protection in Ukraine in the second half of the XIX and early XX centuries) and other.

In the historical-regional aspect the problems of the occurrence, establishment and development of the residential care facilities, orphanages and children's shelters were studied by such scientists as A. Ablyatypov (the establishment and development of the residential care facilities in the Autonomous Republic of Crimea in 1920-2000 years), O. Iljchenko (the upbringing of homeless children in the Poltava region in the twenties - thirties years of the XX century), N. Kasyanova (the struggle with homelessness and neglect in Donbass in 1943-1953 years), M. Solovey (the activity of orphanages of Donbass in 1943-1965 years) and other.

The question of the organization of life of the residential care facilities had studied by Transcarpathian scientists such as B. Kachur, A. Mashkarynets-Butko, P. Strichyk, M. Talapkanych, V. Khymynets. However it should be noted that their studies have interpreted mainly the development of the residential care facilities on the period after 1945 year when the Transcarpathia became part of the Ukrainian Soviet Socialist Republic.

However the analysis of historical and pedagogical literature and scientific works allows us to conclude that today in pedagogical science the genesis of the establishment and development of the residential care facilities in the Transcarpathia is not fully disclosed during the period when the edge 
was part of other European states, namely until 1945.

The goal of this article is to find out the peculiarities of the establishment of the residential care facilities in the Transcarpathia at beginning of the XX century during his stay in the Austro-Hungarian Empire.

Materials and methods. In this publication the author examines the legislative documents of the Hungarian kingdom (The Law VIII "On State Children's Shelters" (1901), the Law XXI "About Children Under the Age of Seven and in Need of State Assistance" (1901)), which regulated the establishment and development of the children's shelters, orphanages, residential care facilities and also provided social care of children, which needed state support. In order to conduct a comprehensive study and achievement of the set goal we used the following methods of scientific research as historical and pedagogical, retrospective and chronological analysis, synthesis and generalization which became the basis for the study of organizational aspects of the activities of the residential care facilities; search-bibliographic method for studying archival funds, descriptions, etc.

Results and their discussion. The period we are investigating from 1901 till 1919 is relatively small period of time with almost a thousand years of history of the Transcarpathian lands in the Austro-Hungarian Empire. The Transcarpathia of beginning of the XX century was the object of multidimensional research of domestic and foreign historians. So the issues of socio-economic development have been reflected in the writings of H. Biderman, V. Iljka, I. Kolomyiets, V. Mytsyuk and other; political and cultural life was studied by I. Dulishkovych, Yu. Zhatkovych, V. V. Zadorozhnyi, A. Olashyn and others; the development of education and schooling was studied A. Bodnar, V. Homonnai, A. Ihnat, A. Chuma and others. The development of historical events in the Transcarpathia during the First World War is systemically outlined in the writings of the Transcarpathian historians I. Hranchak and D. Danylyuk. In this study the author will not carry out a detailed analysis of socio-economic, political, cultural and educational aspects which took place in the Transcarpathia in the first two decades of the XX century. We will only try to distinguish those conditions, which in our opinion became the factors of establishment and development of the system of social care institutions for orphans and children deprived of parental care, as well as the residential care facilities for children, who had physical and /or mental disabilities, needed special care and special training and upbringing conditions.

So the beginning of the XX century for the Transcarpathian lands that were a part of Austria-Hungary was characterized by the same changes that took place in the life of Austria-Hungary as a whole. And so these were reforms in the agrarian and forestry sectors, in the industrial sector, reforms in the development of infrastructure in cities and towns, etc. In the towns and small towns of the Transcarpathian region in the period under our investigation the socio-economic growth was more pronounced in comparison with the countryside especially in remote and mountainous villages. The researchers of the history of the Transcarpathia on this issue had said the following: "the towns of the Transcarpathia became also the main cultural centres where there were not only initial ones but also secondary and secondary specialized educational establishments, here were organized industrial exhibitions and manufacturing products, cultural and educational organizations were created, printing and publishing houses were founded etc." [1, p. 322]. Here it was ob- served the gradual development of machine industry, the cooperative movement has become widespread. One of the conditions for the transfer of the centre of vital activity of the region from the countryside (particularly mountain areas), to the towns and small towns was the attraction of foreign capital which led to the intensive construction of railways and roads which led to changes in the geography of industry, agriculture and trade, had accelerated the process of social division of labor, rapid growth of towns, etc.

But it should be noted that proposed by the Hungarian government reforms had not always had a favorable impact on the vital activity of the population of the Transcarpathia. For example, the agrarian reform, which was carried out in several stages $(1853,1868,1871,1908$ years) had contributed to enrichment and had defended the interests of large landowners. Instead, poorer peasants were forced to sell their agricultural land due to the payment of a large number of taxes and a high rent for land. And this eventually led to a large number of landless farms and caused debts among the poor people of the edge. Hence socio-economic situation of the rural population of the Transcarpathian edge which accounted for more than half of the total population significantly deteriorated. And this led to the displacement of the rural population to towns and small towns, or induced them to emigrate deep into the Austro-Hungarian Empire, and they often emigrate to other continents - to North and South America. These events could not but affect on the emergence of such a phenomenon as social orphancy. When children who lived in rural areas especially in remote and mountainous areas and they had parents were forced to lead a housekeeping on their own. And in the worst case they were forced to resort to begging after moved to towns. As a result of the difficult financial situation of a large number of families living in mountainous and remote areas, the inability to provide complete medical care for children, neglect of the rules of hygiene and sanitation has led to a number of diseases in children: "in the centre of Europe, - is noted in the scientific work of A. Olashyn, - a few hours drive from Vienna is an edge, where typhus and cholera destroy hundreds of thousands of people annually. In many of the villages there are unemployed people and they do not get any help, the children are sick with rickets or tuberculosis and can not attend the school because of the fact that there is only one shirt in the family and it is laid up for debts. ... Nowhere else the hunger has not got such terrible forms, nowhere else there is such poverty, nowhere else the life is not so suppressed as on Verkhovyna" [3, p. 125]. Socio-economic situation has worsened as a result of events related to the First World War (1914 year). As the Transcarpathian territory became a front-line, an army was passing through it, there separate military operations were carried out, which significantly affected and on the already difficult economic and social status of the edge: "the situation was complicated by the fact that the adult male population went to the front, they had passed the housekeeping on women and children" $[1, p$. 365-367].

Consequently, for the Transcarpathian edge, the first decade of the XX century is characterized by such tendencies of socio-economic and socio-political life as: the development of infrastructure, which has led to improved living conditions in towns and small towns; lower living standards in rural areas and in mountainous areas as a result of landlessness of peasants; intensification of migration processes, internal migration (urbanization, migration deep into the Austro- 
Hungarian Empire, emigration to other continents); an increase in the number of social orphans as a result of migration processes and poverty; an increase in the number of children in need of social care due to illness; an increase in the number of orphan children due to the death of their parents during the events and the World War.

At the beginning of the XX century the problem before the Hungarian government had arose with particular attention to the issue of the creation of special facilities which could not only ensure the full maintenance of orphans and children in need of special care, but also to ensure their complete development, education and upbringing. First of all, it was necessary to improve the regulatory framework for the establishment and development of the residential care facilities. To this end, two important laws were created by the government: Law VIII "About State Children's Shelters" (1901year) [6] and Law XXI "About Children Who Have Reached the Age of 7 Years and Need State Assistance" (1901year) [7].

We will consider the main provisions of these documents. The Law VIII "About State Children's Shelters" which was adopted by the government in 1901 year. It consists of eight paragraphs. The subject which is covered by this law were children who are officially considered abandoned and they are under the age of 7 years. So in paragraph 1 it is stated that for this category of children it is necessary to open state centres for child care (children's shelters) both in the city Budapest and in other regions of the country. In particular "state-owned children's facilities in other regions of the state, - is noted in the document, - can be created provided availability of children's facilities there and the capacity of local communities to ensure their livelihoods properly" $[6, \S 1]$. In state children's shelters can be only sick children, underdeveloped as well as those who need special attention and medical care; other children are arranged outside such facilities $[6, \S 2]$. After all, it is known that the state tried orphaned children in the presence of relatives or close persons to convey, first of all in family forms of education. In their work children's shelters were guided by the Law XV "On Preschool Education" (1891 year) - for children from 3 years, and the Law XXXVIII "On People's Education" (1868 year) - for children who are under the age of 6 years $[6, \S 3]$. Supervision over their implementation was carried out by the Board of Directors. It should be noted that the effect of these laws was obligatory not only in relation to children in the children's shelter, but also to children who were outside of them ie brought up in families. As regards the staff of children's shelters, their duties correspond to the official duties of the staff of public medical institutions $[6, \S 6]$. The financial side of the activity of state children's shelters is regulated by paragraphs 4-5. So as to cover the costs of building and equipping regional state children's shelters, including in the Transcarpathia [here: the Transcarpathian lands were part of Austro-Hungary - a note of Ch. M.], it is necessary to use funds from the administrative prison fund, state fund for the care of patients, including their property, specified in the report of 1899 year. For the construction and equipment of state children's shelters, funds are set in the state budget in a special section under the heading "Investments". The maintenance of state children's shelters, the costs of care, upbringing and education of children living with them or through their intermediary outside the children's shelters, to put on state fund for the care of the sick in accordance with paragraph 3 of paragraph d of Law XXI of 1898 year $[6, \S \S$
4-5]. Responsibility for the implementation of the Law VIII "On State Children's Shelters" is entrusted to the Minister of the Interior and the Minister of Finance. In particular, the Minister of Internal Affairs is also authorized to organize state children's shelters; to determine the conditions and ways of the registration, maintenance, care and upbringing of children in these institutions or in similar charitable private institutions and organizations, which co-operate with the state fund of care for the sick; o regulate joint state and public events by introducing, if necessary, amendments to the laws $[6, \S \S 7-8]$.

Relating to the Law XXI "About Children Who Have Reached the Age of 7 Years and Need State Assistance" (1901year) then the subjects of this Law are children who have already reached the age of 7 years and who can not be placed in municipal or private orphanages or in other charitable institutions or organizations. In particular, until the age of 15 these children remain in state orphanages, or they can live in orphanages or in reliable guardian in the first place it is farmers or artisans $[7, \S \S 1-2]$. It is important that this Law provides the protection of the gifted and talented pupils of orphanages, because, according to paragraph 2 , with the purpose of further development of the abilities of such children the administration should provide training in various educational institutions (schools, gymnasiums, seminaries, craft schools, etc.) both state and private, on complete state maintenance. As for the financial aspects, the costs of care (attention, upbringing and education) for children aged 7 to 15 years, who are in state children's shelters, carried out by municipal authorities. Since the beginning of 1902 for the maintenance of abandoned children who have reached the age of seven is allocated from the budget of the Ministry of Internal Affairs of Hungary grants for the amount of 400,000 crowns per year. These grants primarily directed to the care costs for abandoned children from among low income or unsecured families. State funding was allowed to be allocated to private organizations and institutions that can accept abandoned children from 7 to 15 years of age not more than $1 / 4$ of the total amount. With the permission of the Minister of the Interior under the effects of annual reporting in the presence of surplus funds for guardianship and reserve funds (interest on own bank deposits, banking operations, surplus of expenditures) are not tied to other purposes, since 1901 to use them for maintenance of abandoned children who have reached the age of seven within the district and urban municipalities. Charitable contributions were also used for the maintenance of children's shelters. So in accordance with paragraph 3 and the introduction of paragraphs 4-5 of this Law charitable donations and donations have the right to exercise as well as for the purpose of their even distribution allowed to unite all the communities that are part of the municipality. And in accordance with paragraphs 9, 13 of Law $\mathrm{XV}$ of 1883 year the preferential tax within the same municipality no more than $1 \%$ had the right to be established. It had deducted from the tax on land, housing, entrepreneurship, miner's tax, income tax, etc. Municipal Districts, which were endowed with the right to spend money in accordance with paragraph 3 of this Law had the right to dispose of funds, obtained through preferential tax, and also had to be responsible for the costs, which were received from charitable foundations and donations [7, $\S \S 4-6]$. Responsibility for the implementation of the Law XXI "About Children Who Have Reached the Age of 7 Years and Need State Assistance" had relied on the Minister of the Interior and the Mi- 
nister of Finance.

Thus taking into account the consequences of the socioeconomic situation, which had happened in this edge in the early XX century, as well as legislative regulation of the activities of the residential care facilities the preconditions were created for their opening in Transcarpathia. During this period there were functioning such institutions as Mukachiv Orphanage for Girls, Uzhgorod School for the Deaf, Vynohradiv (Nadisevlyushsiky) orphanage. It is important to note that information about the activities of these institutions is extremely limited in the scientific literature. So from the history of the Uzhgorod school for the deaf, it is known that during 1901-1904 years with the assistance of school inspectors Shandor Hidoshi and Jozhef Benke negotiations were held on the allocation of premises to create a school for hearing impaired children with the Hungarian government and the authorities of the town Uzhgorod. For the first time 13 pupils came to study in 1904 year. Among these children were also children from wealthy families who paid for 405 crowns. And there were also children from low-income families, who were in complete state aid in accordance with the above Laws VIII and XXI. Every year the number of children in the institution had increased. Four years later, in the 1913-1914 academic year, 86 children had already studed at this school. There were 5 teachers and 2 tutors in this school as well as a physician who worked on a voluntary basis. The functioning of the school was allocated as funds from the state budget (The Ministry of Religion and Public Education allocated 2000 crowns) and charitable contributions (the Union of the Deaf had allocated 300 crowns, the King of Austria-Hungary had allocated 1000 crowns, Mr. Banklin, the director of a chemical plant in the village Perechyn, had allocated 100 crowns) [2]. With the onset of military action, schooling was stopped for almost one year as the teachers had entered the army, and in the walls of the school there was a hospital.

In 1907 year Vynogradiv (Nadisevlyushsiky) orphanage was opened for orphan children who had physical or mental disabilities. However, in 1908 it was passed to the Edge Society for the Protection of Children. This Society reorganized the orphanage into a labour colony for morally depraved children aged 12 to 21 years. The primary school for children from 12 to 16 years old, craft school for children from 16 to 21 years old, carpentry, shoe and tailor's workshops was opened in this colony. Also in the colony was organized a plot for growing vegetables and fruit trees and 1 ha of vineyard for school needs. A total of 150 boys were brought up at this school-colony. In the 1910-1911 academic year in the primary school at this orphanage the class was opened for pupils, who had deviations in mental development. Classes with children were conducted by the teachers, who had special education and qualified pedagoguedefectologist. The events of World War I also intervened in the livelihoods of this facility: children with developmental defects were returned to their families, orphan children were left at school; school and workshops stopped working; a military hospital was opened in the main building [4, h. 8-9].

Regarding the organization of the children's homes in Austria-Hungary and in particular in the Transcarpathia the active role was played by the Ministry of Religion and Public Education. Every year this Ministry issued the orders, the contents of which the school district inspectors, directors of educational facilities and teachers were obliged to bring to the notice of schoolchildren. In particular it was about collecting charitable funds for ill pupils and for the educational facilities where ill children were studying [5, sheet 1]. Such actions contributed to the education of the students of charity, willingness to do good deeds, and so on.

Conclusions. Consequently, the establishment and development of the residential care facilities in Transcarpathia in the early XX century above all was due to socio-economic factors. The consequence of these factors was the increase in the number of orphans, including social, children with physical and mental disabilities who needed special conditions of stay. Significant was the adoption in 1901 of such laws as the Law VIII "About State Children's Shelters" and the Law XXI "About Children Who Have Reached the Age of 7 Years and Need State Aid" which regulated the establishment, financial support and functioning of the children's shelters, orphanages and other residential care facilities. Perspective directions of further researches are revealing of features of organization of the work depending on the specifics of the residential care facilities, studying of the content of the work on upbringing and educational work in such facilities, the peculiarities of the organization of cooperation with families, public organizations, etc.

\section{REFERENCES}

1. Hranchak, I.M., Danyliuk, D.D., Balahuri, E.A. (1993) Narysy istorii Zakarpattia. Tom I (z naidavnishykh chasiv do 1918 roku) [Essays on the history of Transcarpathia. Volume I (from ancient times to 1918)] Uzhhorod: Hosprozrakhunkovyi redaktsiinovydavnychyi viddil Zakarpatskoho oblasnoho upravlinnia po presi, p. 436

2. Marynkevych, M.V. (2006) Teplo nashykh ruk [The warmth of our hands] Uzhhorod: KP «Uzhhorodska miska drukarnia», p. 136

3. Olashyn, A.V. Istoriia Zakarpattia [History of Transcarpathia] Mukachevo, p. 212

4. Popadych, M.F. (1959) Z dosvidu roboty Vynohradivskoho

dytiachoho budynku №3 [Work experience of Vinogradiv orphanage №3] Vynohradiv: Drukarnia Zakarpatskoho oblasnoho upravlinnia kultury, p. 116

5. State Archives of Transcarpathian region, F. 1498, descr. 2, c. 1394, p. 21

6. 1901. évi VIII. Törvénycikk az állami gyermekmenhelyekről [VIII. Law on public child care facilities] (h.p.). - Retrieved from: https://1000ev.hu/index.php?a=3\&param $=6822$

7. 1901. évi XXI. Törvénycikk a közsegélyre szoruló 7 éven felüli gyermekek gondozásáról [XXI. Law care for children older than 7 years in need of public assistance] (h.p.). - Retrieved from: https://1000ev.hu/index.php?a=3\&param=6835

\section{Становление учреждений интернатного типа в Закарпатье начала XX века}

\section{М. Т. Черепаня}

Аннотация. Статья посвящена изучению предпосылок и основных тенденций становления учреждений интернатного типа в Закарпатье начала XX века, которое входило в состав Венгерского королевства. В частности, анализируются законы Венгрии, обеспечивающих социальную защиту детей-сирот и детей, которые нуждались в пребывании в специализированных учреждениях по другим причинам, а также регламентирующих деятельность учреждений интернатного типа. В публикации подается историческая справка о деятельности учреждений интернатного типа Закарпатья с 1901 г. по 1919 г., то есть к периоду его отделения от Австро-Венгрии.

Ключевые слова: детские приюты, учреждения интернатного типа, законы, Закарпатье, Венгрия. 